\title{
Article
}

\section{Queering the Family, Reclaiming the Father: Proustian Evocations in Alison Bechdel's Fun Home}

\author{
Michael, Olga \\ Available at http://clok.uclan.ac.uk/33119/ \\ Michael, Olga ORCID: 0000-0003-0523-9929 (2020) Queering the Family, \\ Reclaiming the Father: Proustian Evocations in Alison Bechdel's Fun Home. \\ Biography, 43 (2). pp. 430-457. ISSN 0162-4962
}

It is advisable to refer to the publisher's version if you intend to cite from the work. http://dx.doi.org/10.1353/bio.2020.0036

For more information about UCLan's research in this area go to http://www.uclan.ac.uk/researchgroups/ and search for < name of research Group>.

For information about Research generally at UCLan please go to http://www.uclan.ac.uk/research/

All outputs in CLoK are protected by Intellectual Property Rights law, including Copyright law. Copyright, IPR and Moral Rights for the works on this site are retained by the individual authors and/or other copyright owners. Terms and conditions for use of this material are defined in the policies page.

\section{CLoK}

Central Lancashire online Knowledge www.clok.uclan.ac.uk

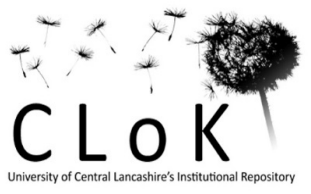




\section{Queering the Family, Reclaiming the Father: Proustian Evocations in Alison Bechdel's Fun Home}

\section{Abstract:}

This essay argues that Alison Bechdel's Proustian allusions in Fun Home structure queer gender and sexuality performances that allow Alison to reclaim and reunite with her distant and ultimately lost father. Thus, it points to the potential value of intertextual readings in identifying positive accounts of queer lives in the field of "autographics."

\section{Introduction}

In this essay, I examine the representation of the father/daughter relationship in Alison Bechdel's Fun Home: A Family Tragicomic (2006), and I propose that via its intertextual references to Marcel Proust's Remembrance of Things Past ([1913-1927] 1981) the graphic memoir recasts the unhappy distant pair into a queerly reunited one. ${ }^{1}$ Fun Home recreates Alison's problematic relationship with her closeted gay father during her childhood, adolescence and young adulthood, when she came out as a lesbian and until Bruce's death four months afterwards. Bechdel reproduced via the comics medium a variety of archival materials, among which family photographs, her parents' love letters and her childhood diaries, to tell the story of growing up with her distant father. In addition, she made an abundance of intertextual references to the literary canon spanning back to the fin-de-siècle and the early-twentieth century, extensively revoking Oscar Wilde, Marcel Proust and James Joyce's works, to name just a few. ${ }^{2}$ In this essay, I demonstrate that Bechdel's nuanced manipulation of comics enriches the narrativization of the problematic father/daughter relationship. My argument is that her comics, infused with intertextual references to Remembrance, allow the possibility for structuring queer subjects and denaturalized gender and sexuality representations that can cause Butlerian trouble, ultimately reuniting Alison and her father in the realm of the graphic memoir. ${ }^{3} \mathrm{My}$ aim is to thus foreground the contribution of Fun Home in queer life writing and the potential of comics as a medium for mediating positive 
accounts of queer lives. In addition, it is to stress the value of intertextual readings for the identification of such accounts within the field of what Gillian Whitlock has defined as “autographics" $(2006,995)$.

\section{Queer autographics, intertextual readings}

Whitlock has coined the term "autographics" to refer to the genre of the graphic memoir and to the kind of critical work it demands. "Comics as sequential art," she writes, "require literacy in the interpretative regiments of art and literature" as well as "the acquisition of new critical skills" in some cases, since the form is "not a mere hybrid of graphic arts and prose fiction, but a unique interpretation that transcends both" (968). Comics demand interdisciplinary approaches and an “imaginative production whereby the reader shuttles between words and images, and navigates across gutters and frames, being moved to see, feel, or think differently in the effort of producing narrative closure," she notes (978). In their introduction to a special issue of Biography on "autographics," Whitlock and Anna Poletti point out that when faced with graphic memoirs, as life writing scholars, we are called to think about how "the frames and gutters of the pages of the comics shape reading and looking, thinking and perception" $(2008, \mathrm{v})$. The medium itself, therefore, demands a kind of readerly engagement with the story it presents that is different from the one a prose or a visual text respectively would demand.

In Fun Home, the imaginative work of closure required by readers as they move from one panel to the next is unavoidably affected by the wealth of its intertextual references. In this case, the "attentive and reflexive reading strategies" triggered by "autographics" require that we pause to investigate how these references become "constitutive" as Whitlock and Poletti argue, of the narrative in their mediation via the comics form (x). Commending upon Bechdel's extensive engagement with books as that is displayed in Fun Home, Valerie Rohy notes that this graphic memoir is an attestation to how "queers are liable to an intense library cathexis" $(2010,355)$. "Those whose difference is antifamilial, somatically unmarked, culturally veiled, and potentially 
shaming," she mentions, "are drawn to lonely stacks and secret research, where the archive enables self-definition" (355). In this essay, I argue that Bechdel's turn to the literary archive and, Remembrance in particular, is not anti-familial because it can be read as enabling the autobiographical subject's reconnection with her father, while also queering each one's representations. Writing about queer biography, Wendy Moffat observes that "in the past few years, the fruit of careful work in the archives has brought new queer lives, and lives newly queered, into the mainstream of American publishing" $(2015,185-86)$. This is also what Fun Home manifests. With her intertextual references to Proust's life and work, Bechdel re-orients readers in terms of how we can interpret Bruce's (closeted) life, and she queers her family dynamics and her autobiographical alter-ego's relationship with her father.

Intertextuality in Fun Home is displayed in various ways. It takes the form of quotation, whereby Bechdel explicitly acknowledges Proust and Remembrance, among others; allusion, which 'is usually woven into the text rather than 'quoted,' and is often rather less precise in terms of wording," and echo, which refers to "a faint trace of [the] text [that] might be quite unconscious" (Moyise 2002, 419). Intertextual references can be identified in the visual and in the verbal register, as well as in the space that is created via the interpretative combination of the two. Because of the graphic memoir's explicit references to Proust's life and art, one may also become predisposed to identify further and subtler allusions. Thus, reading becomes intertextual and meaning is formed through this kind of readerly engagement with the text. Jonathan Culler points out that "the notion of intertextuality emphasizes that to read is to place a work in a discursive space, relating it to other texts and to the codes of that space" $(1976,1382)$. Writing, he proceeds, is similar. "It is the historical praxis of reading made visible" (1383). In Fun Home, the act of "reading made visible" acquires a more literal sense. Bechdel's reading of Remembrance becomes graphically displayed to complicate and enrich the mise-en-scène narrative of the distant father/daughter relationship. Her remediation of Proustian figurative language, transubstantiation and transposition through comics, enables the transformation of Alison and her father from an 
unhappy and distant pair to a queerly reunited one. This is precisely where the value of an intertextual reading of Fun Home lies, as such an approach can unveil the text's positive contribution in "autographics" and queer life writing.

The story of Alison's growing up as a member of what appears as (but is not) a heteronormative family is told through the lens of Bechdel's a posteriori knowledge of her father's secret homosexuality. The memoir shows Bruce striving but failing to impose and maintain the appearance of a perfect family and his failure is associated with how the father/daughter pair also fails to adhere to binary norms of gender and sexuality. ${ }^{4}$ On the one hand, Alison comes out as a lesbian and is drawn in the memoir as a tomboy and a masculine woman despite her father's continuous struggle to enforce a heteronormatively-feminine gender representation onto her. On the other, Bruce is shown in an unsuccessful effort to conceal his homosexuality and to pass as an ideal husband and father. An intertextual reading of Bechdel's references to Proust and Remembrance, nevertheless, allows the unveiling of a layer of meaning that complicates the narrativization of the problematic father/daughter relationship, as well as Alison and Bruce's gender and sexuality performances. Considering Bechdel's Proustian references in meaning formation shows that deviating from the norm, as indicated via Alison and Bruce, can potentially eliminate the distance between the two, queering at the same time, Sigmund Freud's Oedipal Complex theory through what I read as Alison's Oedipal reclaiming of her father. As such, the denaturalized gender and sexuality performances of Fun Home also do away with restrictions and violence that language imposes on certain bodies. ${ }^{5}$

\section{Artifice, fiction and family life}

Bechdel's narrator often comments on how distant her father was and on how he confused fiction and artifice with reality, harming in this way his relationship with the rest of his family. She also explains that understanding Bruce was difficult because “you can’t lay hands on a fictional character” (Bechdel 2006, 84). Reading Fun Home through an intertextual lens however demonstrates that Bechdel seems to have turned Bruce's approach to fiction and reality on the one hand, and to literature, to things and 
family members, on the other, into a positive means through which her autobiographical alter-ego can reclaim her father. Alison herself came out as a lesbian to her parents through a letter, "a remote medium," she points out, since hers was "that sort of family" (Bechdel 2006, 77). Given the distancing impact of the letter and the distance that was always present in her family, she decided to come out via a written narrative because writing and reading were the most effective means of communication, particularly, between herself and her father (see also Freedman 2009; Lydenberg 2017). Indeed, the narrator's caption informing readers about her family and the nature of the letter as a medium is located above a panel showing Alison alone, reading Roget's Thesaurus and sitting at a desk with a notebook, a pen and a typewriter next to her. This arrangement underscores the importance of these items in expressing her sexual identity and in communicating with her parents.

Following her coming out, during a phone conversation, her mother told Alison about her father's closeted homosexuality. The autobiographical avatar asked why she was the person to provide this information as opposed to her father, to which her mother replied that telling the truth was not Bruce's habit. ${ }^{6}$ The narrator then explains that "the line [her] dad drew between reality and fiction was indeed a blurry one" (59). Her caption is located within the visual realm of the panel to foreground the impact of this conflation of the imaginary with the real on the autobiographical avatar. In addition to her father's silence about his homosexuality as a way of not telling the truth and thus mixing reality and fiction, Alison also describes his fascination with Scott Fitzgerald's stories because they were inextricably linked with the author's life, noting that "such a suspension of the imaginary in the real was [... her] father's stock in trade" (65). Bruce's amalgamation between the real, the fictional and the artificial also concerns his obsession with preserving the anachronistic Gothic-Revival style of the house, with imagining himself as a "nineteenth-century aristocrat" and with seducing some of his high-school students within the domestic domain (60). As Alison describes this conflation, we see Bruce talking with Roy, with whom he had an affair, in the library, a place that felt "like going back in time" as she explains (65). In the next panel, Helen enters this anachronistic space, and disrupts what is perceived by the adult narrator as her father's 
attempt to seduce Roy, to inform Bruce that their son John was waiting to be picked up by him at Cub Scouts for half an hour. Alison explains that living with her father's conflation of the real with the imaginary "took a toll on the rest of" the family (65). As such, this burden becomes associated with how Bruce's homosexuality becomes embedded in the family structure and unsettles its function as his heteronormative disguise, which he unsuccessfully struggled to maintain.

His real/artificial mixing also concerns how he treated objects, as well as the spatial domain of the family home, similarly to how he treated his actual family. Early on, Alison informs readers that her father "would perform [...] dazzling displays of artfulness" (9). Bruce is visually embodied standing on a scaffolding, holding a decorative frame that he would attach to the façade of the house to preserve its Gothic-Revival style. That he is positioned at the highest level of the family home evokes his patriarchal dominance and authority over how both the house and the family it hosts look like. The panel depicting the original version of the Bechdel home, built in 1867, shows in front of it what can be interpreted as the family that resided therein (fig. 1). The dominance of the father in the panel is highlighted by the dark colour of his suit and through his central position in front of a carriage with his wife and three children being further removed in the background. Looking at this picture, it is possible to infer that Bruce attempted to restore "home" in its original form both in terms of how the actual building looks like and in relation to its association with what is framed through this family photograph as a flawless nineteenth-century patriarchal family (see also Lydenberg 2017). Consequently, the Bechdel dwelling place comes to spatially embody the family itself and Bruce's "dazzling displays of artfulness" refer both to the house and to his family (Bechdel 2006, 9; see also Scherr 2011; Lydenberg 2012; Larson et al. 2012). 


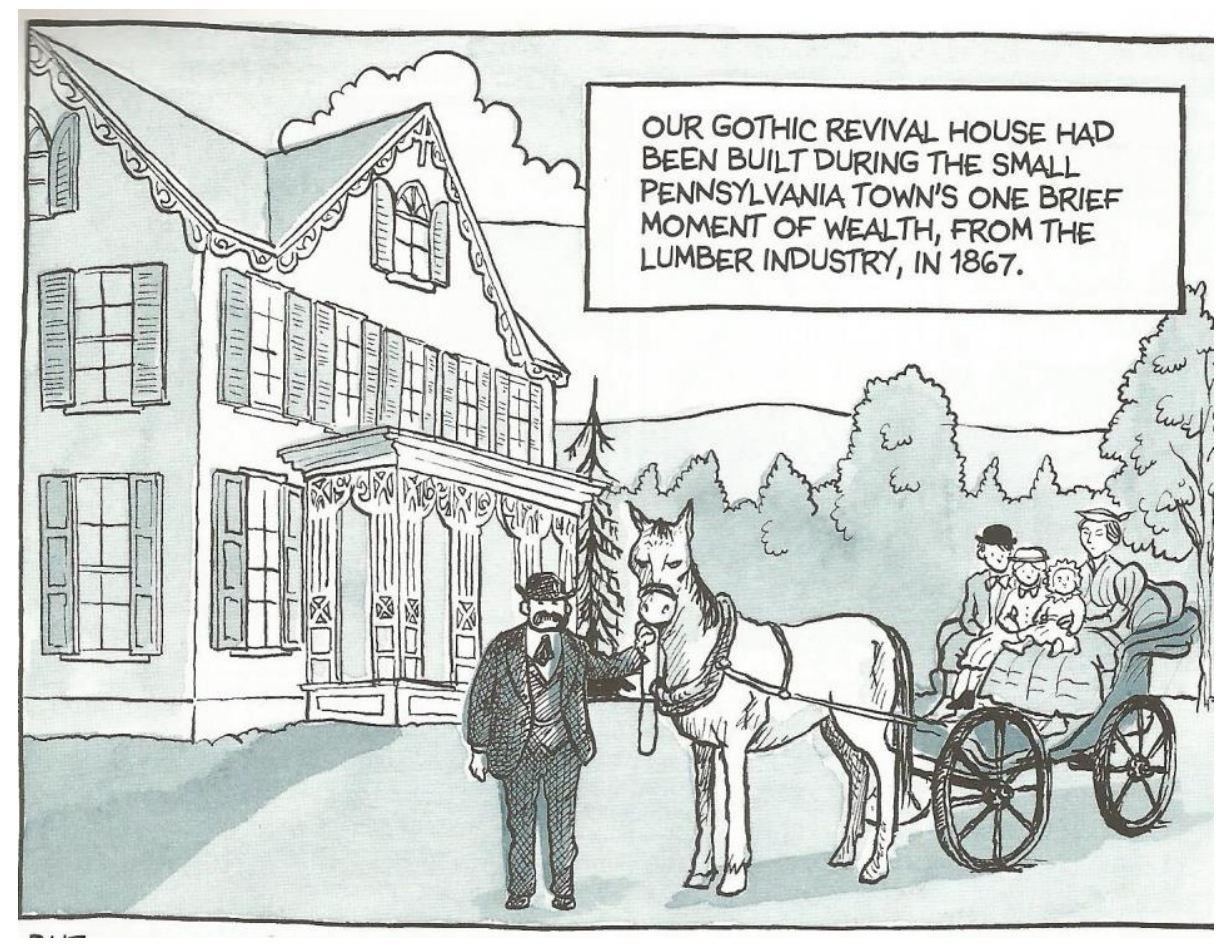

Figure 1: Panel 1, page 8 from: FUN HOME: A Family Tragicomic by Alison Bechdel. Copyright @ 2006 by Alison Bechdel. Reprinted by permission of Houghton Mifflin Company. All rights reserved.

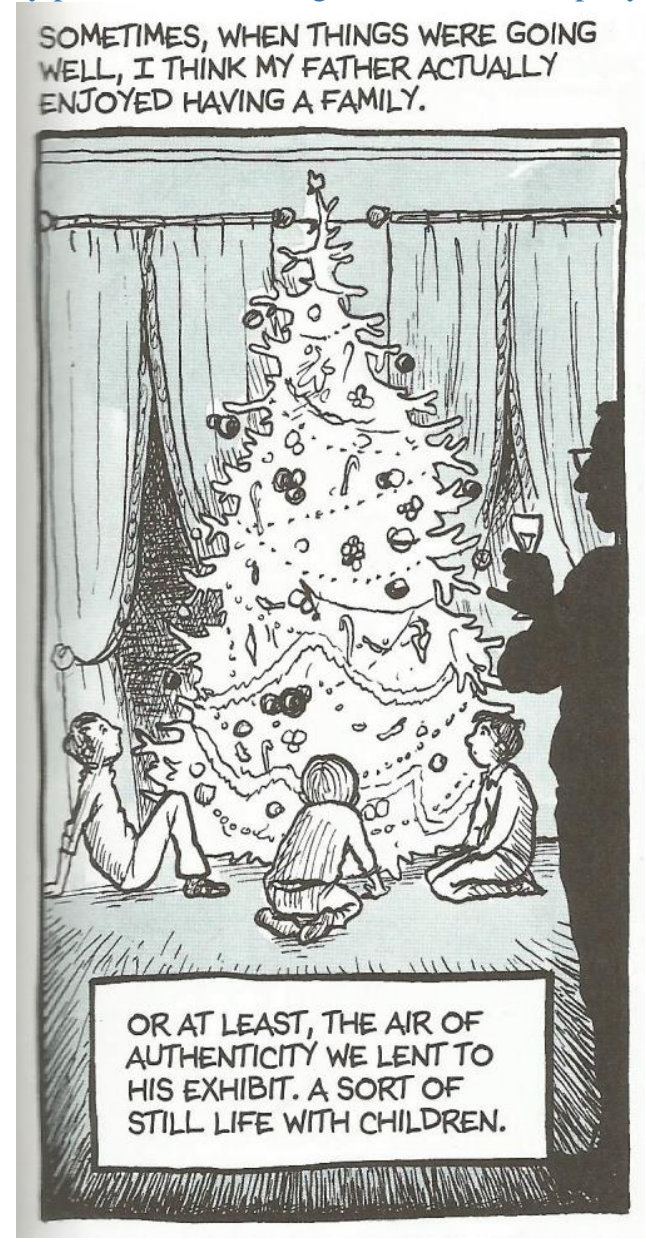

Figure 2: Panel 1, page 13 from: FUN HOME: A Family Tragicomic by Alison Bechdel. Copyright (C) 2006 by Alison Bechdel. Reprinted by permission of Houghton Mifflin Company. All rights reserved. 
Indeed, Alison talks about her family as her father's work of art (fig. 2): "Sometimes," she mentions, "when things were going well, I think my father actually enjoyed having a family" (Bechdel 2006, 13). Beneath this caption, a frame includes a visual depiction of a decorated Christmas tree, with Alison and her two brothers sitting on the floor around it, gazing at it. Bruce's dark silhouette is situated on the side of the panel at a distance and he is drawn holding a drink, while looking at the tree and his children from afar. Both the children and the Christmas tree seem to become framed through his artistic vision as conflated into an artwork - an installation of sorts and Bruce is presented more as a connoisseur of art and less as a father figure. The balance of this visual image is ruptured by the narrator's caption that intervenes again within the visual realm of the panel to clarify that her father enjoyed having a family "or at least the air of authenticity we lent to his exhibit. A sort of still life with children" (13). Bechdel uses artistic discourse to describe her family life and like Bruce, she conflates the two realms. The narrator further explains that she "grew to resent the way her father treated his furniture like children, and his children like furniture" and notes that she and her brothers were imperfect unlike his perfect objects, possibly disappointing him (14). Irrespective its toll on the family however, and the distance it created between himself and Alison, Bruce's problematic approach to art, literature, objects and family members is taken up by Bechdel to allow the performance of a distant, queer reconnection between the father/daughter pair. In the book's fourth chapter, "In the Shadow of Young Girls in Flower," Proustian elements are conflated with the realm of the graphic memoir to produce what I perceive as the reconfiguration of the unhappy distant father/daughter pair into a queerly reunited one.

\section{Bechdel's Proustian evocations (I)}

The middle chapter of the graphic memoir has the same title as the second volume of Proust's Remembrance, which introduces codes that articulate unspeakable homosexual desires for readers who are aware of its system of communication. These codes reappear in Fun Home to construct an implicit reconnection between Alison and Bruce. In the History of Sexuality, Michel Foucault 
describes the imposition of silences around specific sexual matters, like homosexuality, noting that:

Silence itself - the things one declines to say, or is forbidden to name, the discretion that is required between different speakers - is less the absolute limit of discourse, the other side from which it is separated by a strict boundary than an element that functions alongside the things said, with them and in relation to them [...]. There is no binary division to be made between what one says and what one does not say; we must try to determine the different ways of not saying such things, how those who can and those who cannot speak them are distributed, which type of discourse is authorized, or which form of discretion is required in either case. $(1998,17)$

During the turn of the previous century, medical and scientific discourses were authorized to examine, describe and name the homosexual type (see Foucault 1998). At the same time, writers like Wilde and Proust turned to literary fiction to encode and silently represent what were perceived as unnatural, and therefore unspeakable, sexual desires, which were in the process of being scientifically defined. Approximately a century later, Bruce, a closeted gay father living in the small town of Beech Creek, refuses to speak about his homosexuality and struggles to maintain the appearance of the ideal husband and father putting a strain on the rest of his family.

Drawing parallels between the literary structuring of Proust's sexual inversion in Remembrance and Bechdel's representation of Alison and Bruce in the fourth chapter of Fun Home, allows the interpretation of the silences existing in the Bechdel family home as queer performative acts that can discursively reunite the father/daughter pair. ${ }^{7}$ Indeed, similarly to Foucault, Eve Kosofsky Sedgwick explains that sexual silence is as performative as the speech act of coming out. However, in order for such silences to be understood, interlocutors need to have “"mutual [...] established practices of interpretation"” $(1991,4)$. If the readers of Fun Home share 
practices of interpretation that can decipher sexual inversion in Remembrance, then they can identify the graphic representation of queer traits in Alison and Bruce's gender and sexuality performances that can ultimately unite the two. Deciding, therefore, whether Fun Home merely presents an unhappy, distant father/daughter pair or a potentially happy, queer one depends on the extent to which readers pay attention to the impact Bechdel's references to Proust on the narrative. Thus, their role is crucial in the process of meaning formation. ${ }^{8}$

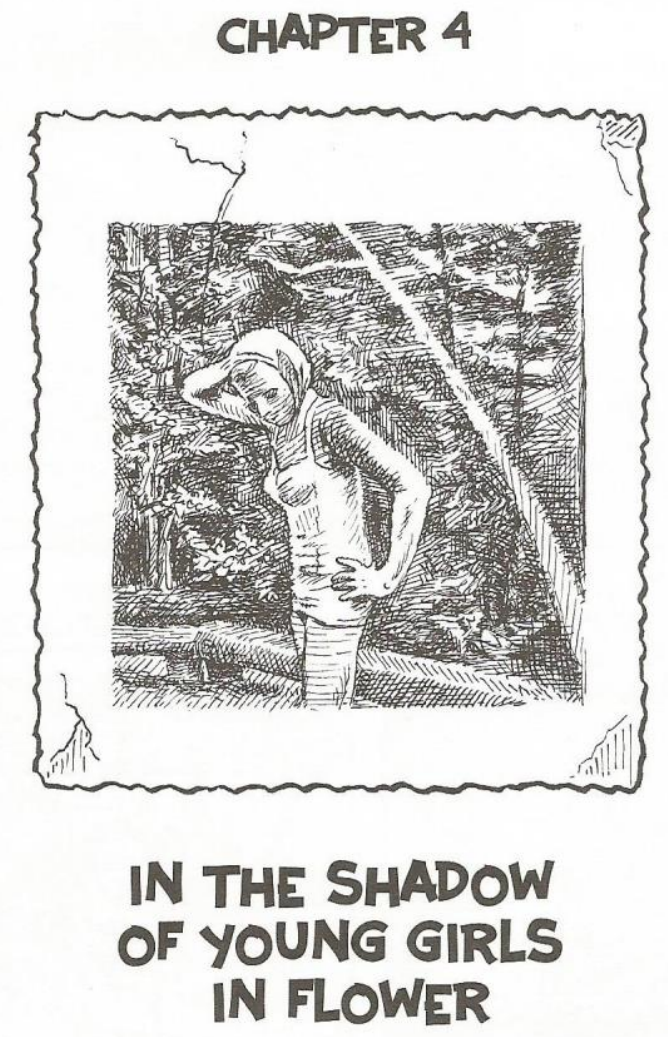

Figure 3: Chapter title page 87 from: FUN HOME: A Family Tragicomic by Alison Bechdel. Copyright (C) 2006 by Alison Bechdel. Reprinted by permission of Houghton Mifflin Company. All rights reserved.

The chapter's cover page (fig. 3) includes the title, "In the Shadow of Young Girls in Flower," and a photograph of someone who from afar seems like a woman wearing a bathing suit, posing for the camera in front of trees. That the person in the picture is most likely female can be further assumed by the word "girls" in the title, which could be interpreted as referring to the visual 
component of the page. However, as Hélène Tison explains, "text and image combine to direct the reader toward an erroneous interpretation of the photo" $(2015,356)$. While there is no information about who this person is at this point, the photograph reappears on the final page of the chapter, held by Alison, who tells us that this was her father in his early twenties. There is, therefore, a deliberate ambiguity in relation to this visual depiction of Bruce. That the picture captures him despite the title's description of "girls in flower," unsettles the power of language to enforce cohesion between biological sex and gender representations by naming, for example, someone a girl, or through the use of the gendered pronouns "he" and "she" (see Butler 1993; Butler 2004). This ambiguity, allowed by comics, foregrounds the medium's potential in relation to the performance of "troubling," queer gender identities.

Later, the narrator describes the lexical choices of her father's translated edition of Remembrance, noting that "in [his] edition of Proust, the title of volume four is chastely translated as Cities of the Plain from the French Sodome et Gomorrhe" (Bechdel 2006, 108). As the narrator's use of "Proust" instead of Remembrance to refer to his fictional multi-volume work metonymically substitutes the artwork with its author, her commentary about the English translation of the volume shows how word choices conceal aspects of the title's meaning to present a chaste version of it. Cities of the Plain refers to the Old Testament cities Sodom and Gomorrah, as found in the French original, which have been associated with male and female sexual inversion respectively since the late nineteenth century, leading to the characterisation of male inverts as Sodomites (see Ladenson 1999). Like Bruce, his edition of the particular volume hides, on a superficial level only (the book-cover), the nature of its contents that have to do with the literary articulation of sexual inversion.

In Cities of the Plain, Proust's heterosexual narrator, Marcel, describes the ancient race of inverts, who derive from the cities of Sodom and Gomorrah and "link themselves [...] to that initial hermaphroditism of which certain rudiments of male organs in the anatomy of women and 
of female organs in that of men seem still to preserve the trace" ([1921/22]1981, 653). As such, he reproduces the late-nineteenth century definition of homosexuality as sexual inversion, a model also used by Alison to describe herself in relation to her father (see also Ellis 1933; Chauncey 1983; Bechdel 2006). While the narrator comments on the translator's choices for her father's edition of Remembrance, the visual register of the narrative relates an entirely different incident from Alison's childhood. She and Bruce are in the kitchen, each reading a male-fashion and a gardening magazine, respectively. At this point, then, the narrator's captions seem somewhat irrelevant to the narrative unfolding in the visual register of the graphic memoir.

The narrator further explains that "the original title of volume two is A l'Ombre des Jeunes Filles en Fleurs, literally 'in the shadow of young girls in flower'” (Bechdel 2006, 109). Bechdel chooses the literal translation as a title for her chapter, in contrast to her father's edition, which was translated into "Within a Budding Grove [, shifting] the emphasis primly from the erotic to the botanical" (109). This translation again vails, albeit on a superficial level, the contents of this volume, which refer to the young girls Marcel was looking at from afar, admiring their adolescent androgynous beauty. In addition to Proust's “young girls in flower" that accompany Bruce's titlepage depiction (fig. 3), Bechdel also uses the word "budding" to refer to her autobiographical avatar's developing breasts, which mark her embodied passage to womanhood. It is, she mentions, "the only possible word to describe [their] painful, itchy beginnings [...] at twelve" (109). Alison is drawn wearing a shirt and a sweater that hide her developing breasts. A round inset, however, presents a close-up take of her chest and provides access to her nude body underneath her clothes, revealing a different embodied gender representation than the one she otherwise chooses to pursue, which is more tomboyish than girly. Proust's androgynous adolescent girls are therefore used to facilitate the structuring of both Alison and her father's sexual inversion.

As we process the information concerning the autobiographical avatar's developing breasts, she declares that she wants "a custom-made shirt with cuffs" she had seen in the fashion magazine 
and Bruce is preoccupied with his gardening magazine (109). Prior to this panel, the narrator explains that for Proust "eros and botany are pretty much the same thing" (109). As such, we are guided to interpret Bruce's preoccupation with the gardening magazine and the use of the adjective "budding" to describe the adolescent autobiographical avatar's body as evocative of similar meanings, while the narrator's comments form a connection between Proust's understanding and literary use of botanics and Bechdel's remediation of this metaphor for the structuring of the queer gender and sexuality formations of the father/daughter pair. Having given us the tools to decipher her graphic memoir by explaining that for Proust botanics are inextricably linked to (homo)sexual desire, Bechdel also reconfigures his techniques to articulate the sexual inversion that is common between Bruce and Alison (see also Watson 2012; Schlick 2013).

The narrator often describes what she perceives as her father's effeminacy in contrast to her own masculine tastes. While she was nicknamed "butch" by her cousins, she calls Bruce a "nelly" and a "pansy" (see Bechdel 2006, 97, 15). She further explains that there was "an undefended gap" in her family "which cried out [...] for some plain, two-fisted sinew" and mentions that as a child she compared her father with "the grimy deer hunters at the gas station uptown $[\ldots]$ and where he fell short, [she] stepped in" (96). Presenting herself as the opposite of her father, Alison notes that "despite [his] tyrannical power, it was clear that [he] was a big sissy" (97). In the visual register Bruce holds a flower painting and then forces Alison to wear a barrette, while wearing a military jacket, she states her preference for "a crewcut" (96). To describe her relationship with Bruce, the narrator mentions Proust's references "to his explicitly homosexual characters as 'inverts"” (97). This is, Bechdel writes, an "antiquated clinical term I've always been font of," despite how "imprecise and insufficient" it is in its definition of "the homosexual as a person whose gender expression is at odds with his or her sex" (97). Paraphrasing Proust and the nineteenth-century sexologist Havelock Ellis, the narrator mentions that irrespective of its problems, the term is suitable to describe herself in relation to her father: "Not only were we inverts," she points out, "we were inversions of each other" (98). 
Underneath her caption, in a large panel, Alison and Bruce are standing in front of a mirror, exchanging annoyed gazes while getting ready for a wedding. Alison wants to wear her snickers and her father expresses his wish that they had a "straw hat" for her (98). Captions explain that the autobiographical avatar was wearing the "least girly dress in the store" while her father was wearing "velvet" (98). Her mother stands on the side, outside the mirror frame, excluded from the display of the "inverted" father/daughter relationship, and tells Bruce that he will "upstage the bride" (98). The narrator's captions, situated yet again within the visual realm of the panel, further illustrate the situation, explaining that "while [Alison] was trying to compensate for something unmanly in [Bruce] ... he was attempting to express something feminine through" her (98). Their opposite tastes produced an antagonism between the two - a rivalry that endured through Alison's childhood, adolescence and young adulthood. The term "invert" as used by Proust and taken up by Bechdel to describe her autobiographical subject and her father, is one of the ways in which elements from Remembrance intervene in, complicate and enrich the narrative of Fun Home insidiously and gradually undoing this rivalry.

In addition to her references to sexual inversion and to "botanics" and "eros," Bechdel puts Proust's figurative flower language in relation to its literary articulation of sexual inversion in further productive uses. In the fin-de-siècle context, the "language of flowers" was used in sexology and art to express alternative sexualities, and specifically, sexual inversion. Alison Syme explains that "sexologists frequently used botanical and zoological examples of hermaphroditism to explain both the 'latent organic bi-sexuality of each sex' and the varieties of sexual behaviour 'inverts' exhibited” $(2010,12)$. At a time of its scrutiny and examination, flowers were used as means to describe and understand this type of "deviant" sexuality. "Inverts," as Syme points out, "were not only identified with hermaphroditic flowers [...] they were also imagined as pollinators" (12). Shifting her discussion from the science of sexology to the artistic field, she notes that "whether identifying as pollinators or plants, invert artists working in diverse disciplines mobilized the ideas of cross-fertilization and the hermaphroditic sexuality of flowers to 'naturalize' sexual 
inversion" (12). In Cities of the Plain, in addition to reproducing the fin-de-siècle perception of homosexuality as inversion, Proust's heterosexual narrator, Marcel relates an incident he observes from afar concerning a scene of sexual intercourse between two male inverts - Mr. de Charlus and Jupien - and he describes it in parallel to the pollination of an orchid by a bumble-bee. "M. de Charlus," he notes in his account, "disappeared through the gate humming like a great bumble-bee [...] so long awaited by the orchid" (Proust [1921/22]1981, 628). By making this comparison and introducing Jupien as an orchid, a flower which took its name from the Greek word orchis (testicle), and Mr. de Charlus as a bumble-bee, the narrator uses the language of flowers to articulate male same-sex desire (see also Syme 2010).

The possibility to construct meanings that are otherwise unspeakable exists according to Proust's narrator in the visual arts and the use of poetic metaphor. Moving from the use of metaphor to the field of visual arts, he notes that painters can recreate the objects they depict through their artistic vision and observes

A charm in a sort of metamorphosis of the objects represented, analogous to what in poetry we call metaphor [...]. If God the Father had created things by naming them, it was by taking away their names or giving them other names that Elistir [Proust's fictional painter] created them anew. The names which designate things correspond invariably to an intellectual notion, alien to our true impressions, and compelling us to eliminate from them everything that is not in keeping with that notion. (Within [1919]1981, 893).

Almost a century earlier, Marcel's comment evokes Butler's (2007) descriptions of the restrictions that grammar imposes on what is speakable and thinkable, and of the violence naming processes impose on human subjects in heteronormative hegemonic systems. If we understand Marcel's comment about "God the Father's" naming as similar to Butler's analysis of the power of language to produce specific kinds of subjects, and sexual inversion as one of the meanings stripped off from 
human beings in their definition as always-already heterosexual, then visual arts and poetic metaphor can be used to articulate such meanings. ${ }^{9}$ In Cities of the Plain, through his description of male same-sex intercourse as an orchid's pollination by a bumble-bee, itself a visual image constructed in words, Marcel speaks the unspeakable. The surrounding natural environment, and particularly, hermaphroditic flowers and their pollinators, viewed through an artistic vision that invests them with the ability to express sexual inversion, become essential in this rhetorical construction (see also Fowlie 1975; Bal 1997). Hence, Proust's figurative flower language constitutes, as Julia Kristeva writes, a metamorphosis that achieves "the transubstantiation of the irrational qualities of matter and life into human words" $(1993,58)$.

That the comics medium is based on the combination of words and images renders the graphic memoir a fertile space for the proliferation of such "irrational" qualities, because figurative uses of language can be combined with pictures in ways that complicate and enrich their meaning. Interpreting the relationship between narrators' captions, drawn characters, speech and thought balloons in panels arranged next to one another page after page allows readers to decipher complex expressions of gender and sexual identities in Fun Home. Empty spaces between panels, otherwise known as gutters, require us to provide cohesion between narrative fragments, allowing us to also pause and think about how the visual informs the verbal and vice versa (see McCloud 1994; Chute 2016). This is why I am arguing for the potential offered by comics as a medium in relation to the artistic expression of "troubling" gender and sexuality performances that unsettle the cohesion between sex, gender and hetero-sexuality. In Fun Home, comics are infused with the Proustian language of flowers to achieve, inter alia, the anachronistic rhetorical encoding of Bruce's homosexuality.

"In the Shadow of Young Girls in Flower" starts with the narrator explaining that her "father died gardening" (89). Next, she relates that "of all his domestic inclinations, [her]father's decided bent for gardening was the most redolent [...] of that other, more deeply disturbing bent," 
implicitly alluding to his secret homosexuality, connecting, like Proust, "eros" with "botanics" (90). Proceeding, she wonders: "What kind of man but a sissy could possibly love flowers this ardently?" (90). On the same page (fig.4), the first panel shows Bruce explaining to Alison how to plant a bulb as she states her distaste for flowers. The second panel illustrates, through a longdistance take on the garden, the exaggerated, almost artificial, presence of floral arrangements outside the house, with Alison watering them and seeming too small in comparison to them. A narrator's caption intervenes in the visual narrative to explain that their "home was an efflorescence of bulbs, buds, and blooms, flowers wild and cultivated, native and imported, flowering vines and trees" (90). As such, verbal alliteration, combined with visual images, foregrounds the excessive presence of flowers in the house. 
OF ALL HIS DOMESTIC INCLINATIONS, MY FATHER'S DECIDED BENT FOR GARDENING WAS THE MOST REDOLENT TO ME OF THAT OTHER, MORE DEEPLY DISTURBING BENT.

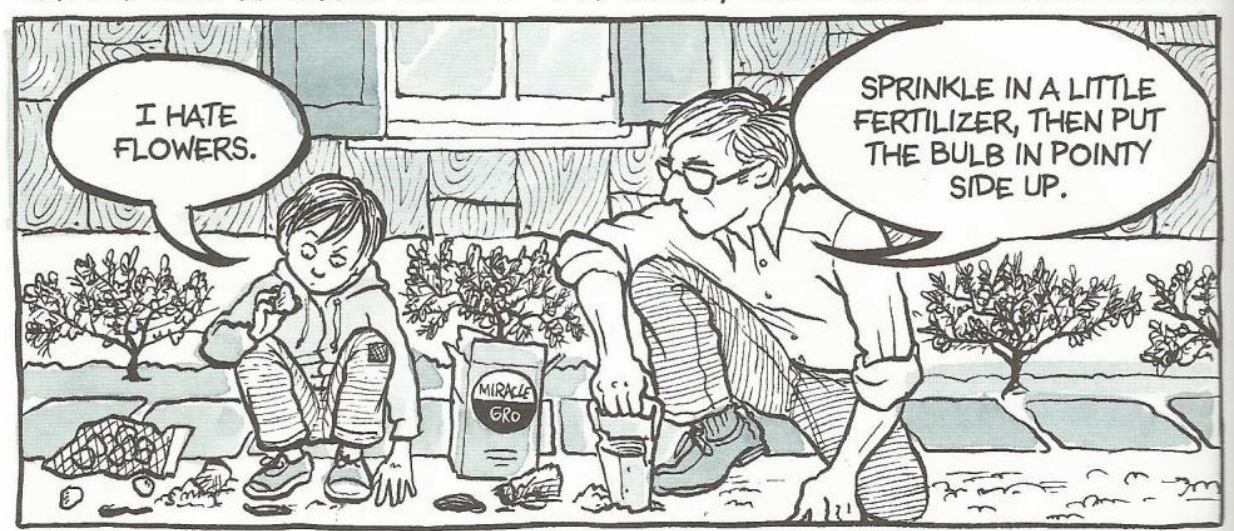

WHAT KIND OF MAN BUT A SISSY COULD POSSIBLY LOVE FLOWERS THIS ARDENTLY?

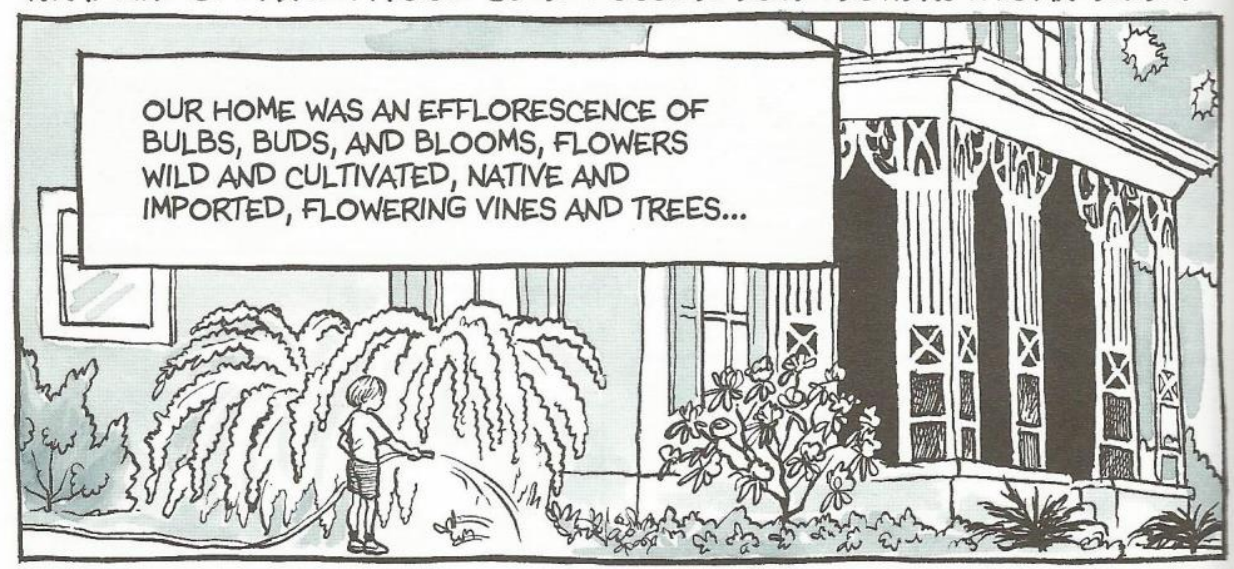

...SILK FLOWERS, GLASS FLOWERS, NEEDLEPOINT FLOWERS, FLOWER PAINTINGS AND, WHERE ANY OF THESE FAILED TO MATERIALIZE, FLORAL PATTERNS.

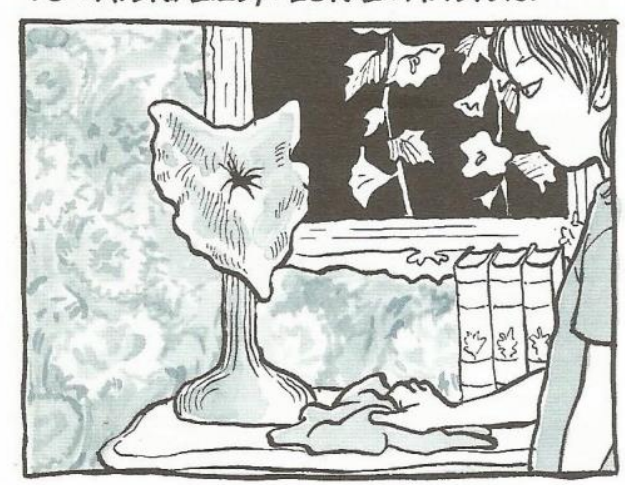

AT EASTER, DAD WOULD PAINT GOOSE EGGS WITH TWINING TEA ROSES.

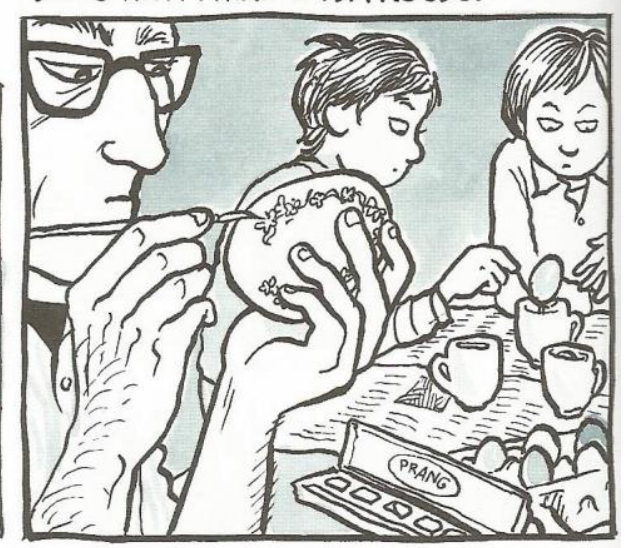

Figure 4: Full page 90 from: FUN HOME: A Family Tragicomic by Alison Bechdel. Copyright @ 2006 by Alison Bechdel. Reprinted by permission of Houghton Mifflin Company. All rights reserved.

The third panel includes a close-up take on the autobiographical avatar inside the house, standing in front of a painting of flowers, cleaning one of Bruce's artificial, decorative flowers with a bored look. A close-up take on Bruce shows him painting flower decorations on Easter eggs together with Alison and one of her brothers at the background, who are engaged in the process of 
dying the eggs. The contrast between Bruce and the children, underscores the latter's attention to perfecting his floral decorations. Perceiving Bechdel's meticulous reproduction of Bruce's attentive preoccupation with flowers as a repetition of the Proustian figurative flower language can lead to its interpretation as an artistic, metaphorical articulation of his secret, unspoken homosexuality. Richard Meyer (2002) writes that the repression and censorship of the visual expression of modern gay and lesbian identities has produced strategic uses of metaphorical language and encoded meanings, thus not only erasing their representation but also enabling the proliferation of alternative ways to articulate them (see also Ball 2013). Bechdel's use of the Proustian language of flowers forms one such example in its silent performance of Bruce's homosexuality, demonstrating, at the same time, her intervention in the gay modernist literary canon though her repetition and reconfiguration of Proust's tradition.

Returning to Proust, the narrator also refers to his descriptions of "the pink blossoms of the Hawthorn Hedge" in Swann's Way as Alison, her brothers and father dig up dogwood trees from the mountains to transplant them in their garden (93). The autobiographical avatar asks her father if their activity is legal, suggesting that her father's preoccupation with gardening reaches the limits of the illicit, again implicitly alluding to his sexual affairs with teenage boys, which led Bruce to a court hearing. Later, the narrator mediates more details from Swann's Way: "Through the hedge," she explains, “Proust's narrator could see even deeper into Swann's garden. There, surrounded by jasmine, verbena, and pansies, sat a little girl. The young narrator, failing to distinguish this girl, Gilberte, from the general floral fecundity, instantly fell in love with her" (93). Her description of Gilberte reminds one of Bruce's photograph on the cover page, which visually captures his ambivalent identification with one of Proust's fictional girls in flower. While Alison describes the structuring of Marcel's desire for Gilberte, the process of transplanting the trees in the garden is completed. 
The final panel of the page shows Bruce with his children in what would seem like bonding time between the four of them, if taken out of context and read in isolation, similarly for example, to how a (family) photograph is usually interpreted. However, as we read through Bechdel's graphic memoir piecing fragments together, it becomes clear that this was an enforced activity for the children, indicated, if anything, by their disinterested looks during the process. A narrator's caption within this panel unsettles its superficial appearance as a glimpse into the life of what only seems like a heteronormative family, explaining that "if there was ever a bigger pansy than [her] father, it was Marcel Proust" (93). What comics reveal therefore, as Jennifer Lemberg notes, is life "behind formal [family] pictures" $(2008,133)$. The parallels Bechdel draws between Bruce and Proust lead to an identification between the two, achieved through the comics form and what Gerard Genete defines as "narrative metalepsis." For Genette, the conflation of different diegetic realms in a literary text, defined as "narrative metalepsis," concerns "any intrusion by the extradiegetic narrator or narratee into the diegetic universe (or by diegetic characters into a metadiegetic universe, etc.), or the inverse [... and it] produces an effect of strangeness that is either comical [...] or fantastic" (1980, 234-35). In this essay, I argue that the outcome of Bechdel's "narrative metalepsis" moves beyond the comical and the fantastic towards causing Butlerian trouble by queering the text, Alison's family and her relationship with Bruce. ${ }^{10}$

Continuing her references to Proust, the narrator explains that he "would have intense, emotional friendships with fashionable women ..." (Bechdel 2006, 94). This caption accompanies a panel depicting Helen, Alison's mother, reading Vogue as she is sitting in front of a window that allows us visual access to the garden (fig. 5). In this case, our perspective on the process of transplanting dogwood trees is different. We see from inside the house, where Helen is sat holding her fashion magazine with her back turned against Bruce and the children, being further distanced from what is happening outside. That she is holds the particular magazine relates to Alison's comment about Proust, suggesting that her relationship with Bruce is merely friendly and not erotic. A bold, capitalized onomatopoeic "knock" disrupts the depiction of the family and as we 
move on to the next panel we realize that the cause of this disturbance is Roy. The narrator points out that as opposed to his friendships with fashionable women, "it was young, often straight, men with whom [Proust] fell in love" (94). In the visual register, Helen opens the door and explains to Roy that Bruce is in the garden. Between these two narrative fragments, one is therefore guided to speculate that Roy is the equivalent of Proust's objects of desire for Bruce.

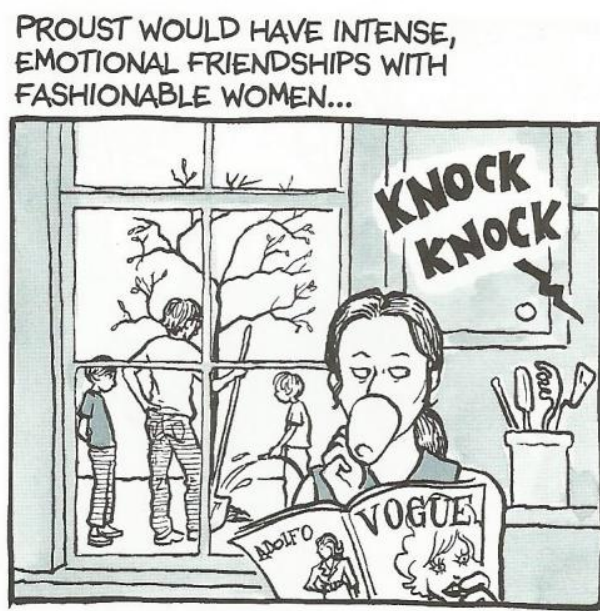

...BUT IT WAS YOUNG, OFTEN STRAIGHT, MEN WITH WHOM HE FELL IN LOVE.

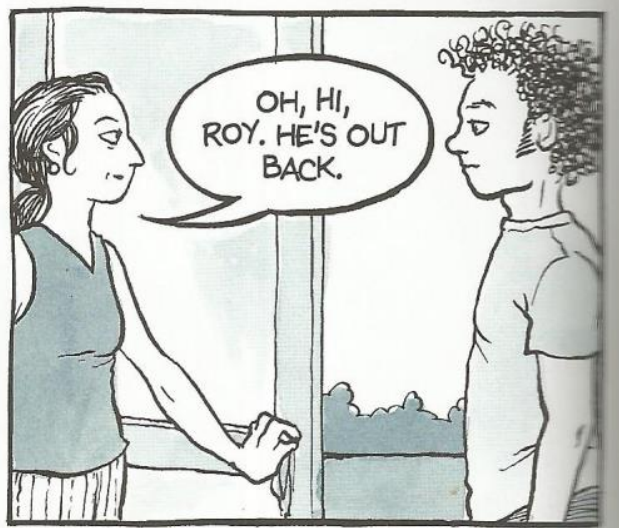

HE WOULD ALSO FICTIONALIZE REAL PEOPLE IN HIS LIFE BY TRANSPOSING THEIR GENDER-THE NARRATOR'S LOVER ALBERTINE, FOR EXAMPLE, IS OFTEN READ AS A PORTRAIT OF PROUST'S BELOVED CHAUFFEUR/SECRETARY, ALFRED.

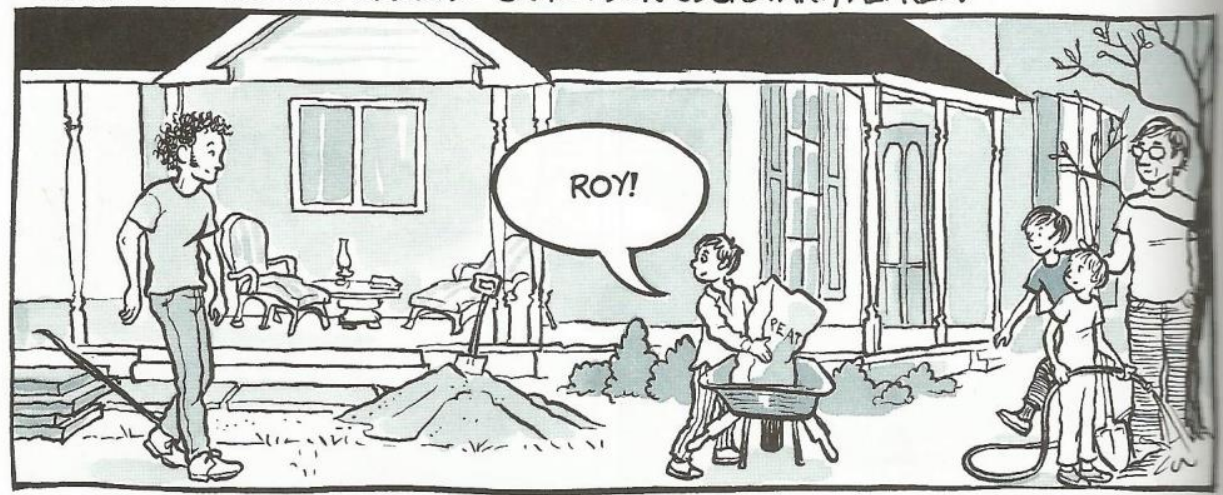

MY FATHER COULD NOT AFFORD A CHAUFFEUR/SECRETARY.

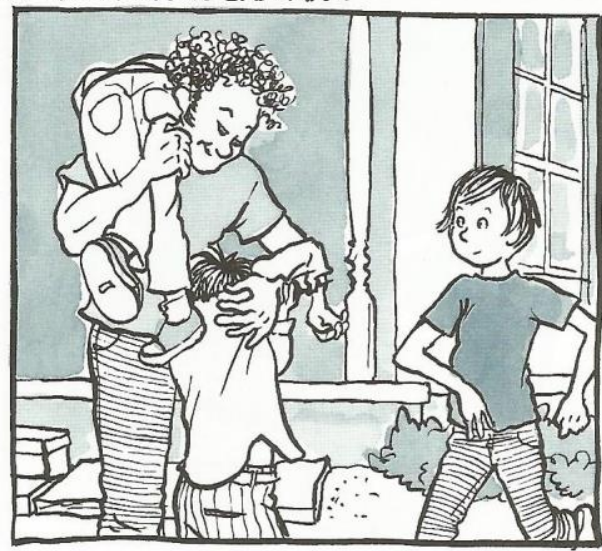

BUT HE DID SPRING FOR THE OCCASIONAL YARDWORK ASSISTANT/BABYSITTER.

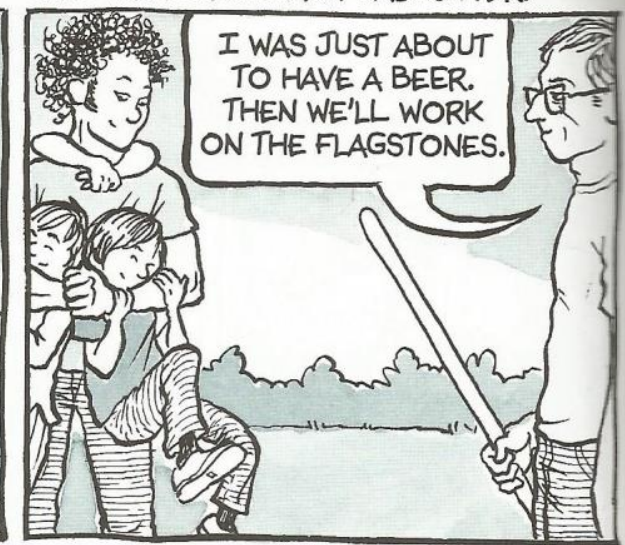


Later, Alison explains that Proust "would also fictionalize real people in his life by transposing their gender - the narrator's lover Albertine, for example, is often read as a portrait of Proust's beloved chauffeur/secretary, Alfred" (94). The visual register offers access in the garden again, Helen disappears from the scene, and we are presented with a long-distance shot on Bruce, the children and Roy, depicting a version of the family that includes Bruce's illicit object of desire in it. When read in relation to the narrative unfolding in the visual register, the narrator's reference to Proust's transposition of his beloved's gender in Remembrance becomes related to Bruce's sexual desire for Roy that is situated within, and partially masked and veiled by, his family. In the two final panels of the page, Alison clarifies that her "father could not afford a chauffeur/secretary. But he did spring for the occasional yardwork assistant/babysitter," while she, as a child, and her brothers are drawn happily playing with Roy (94). Bechdel's queer "narrative metalepsis" conflates Proust's life, the fictional realm of Remembrance and that of Fun Home, to introduce Roy within the family structure. Moving away from the garden, inside the house the children continue playing with him as the narrator refers to her father's objects of desire: "We would cultivate these young men like orchids," she mentions, further explaining that she "admired their masculine charms" as her child autobiographical avatar is drawn being preoccupied with Roy's muscles (95). By using the first person plural pronoun "we," by repeating Proust's "orchid" simile as that is found in Cities of the Plain, and by describing herself and her father as cultivators, Alison becomes embedded in the structuring of her father's homoerotic desire, which is situated in the family home and becomes articulated via the anachronistic, Proustian figurative language of flowers.

\section{Reading Bechdel's Proustian evocations (II)}


Apart from introducing Bruce in relation to Proust in terms of how they chose to veil their homosexuality, the former by having a family, and the latter by disguising it in Remembrance, the narrator constructs a second set of identifications between herself and one of the latter's 'young girls in flower," Albertine, who is interpreted as the fictional version of Proust's beloved Alfred. In Remembrance, Marcel describes the group of girls he watches from afar and his erotic desire for Albertine. Like Alison, Proust's girls are more tomboyish as opposed to heteronormatively feminine. Initially, Marcel describes Gilberte as a girl with a "somewhat boyish appearance" (Swann's Way [1913]1981, 122). He also explains that he first saw Albertine when she was cycling, an activity that at the beginning of the twentieth century was considered inappropriate for girls because it undermined their femininity (Within [1919]1981; see also Strange 2002; Foley 2004). Randolph Splitter points out that Proust's girls are "adolescent [..., on the verge of sexual maturity [and their] frank uninhibited manners [are] less sexual than tomboyish. In fact," he writes, "these athletic, tomboyish girls - the cyclist Albertine who plays golf and 'ferret' and wears a polo cap, the girl who plays leapfrog with the old gentleman, as well as Gilberte $[\ldots]$ - may remind Marcel of his own boyish adolescent self” (1978, n.pag.). If we perceive Proust's girls as sexual inverts, a term Alison also uses to describe herself, then for their masculinity to be explicitly structured, they also need to be introduced in relation to the language of flowers. Indeed, Marcel explains that his desire for them develops and is preserved only when he is situated far from them and observes them through a detached artistic vision that allows their perception as conflated with the background space and the flowers surrounding them. Distance becomes, therefore, essential for the structuring and maintenance of queer desire.

The mistresses, he explains "whom I have loved most passionately have never coincided with my love for them. That love was genuine, since I subordinated everything else to seeing them, keeping them for myself alone [...]. My sole joy lay in seeing them, my sole anxiety in waiting for them to come" (Proust Cities [1921/22]1981, 1164). Marcel's joy in seeing the girls stems from his distant artistic vision that transforms them into sexual inverts. While the narrator idealises 
Albertine in his perception of her as a rose and before being able to physically touch her, his comments after kissing her demonstrate the collapse of his desire in attaining her (see also Guenther 2010):

But alas - for in this matter of kissing our nostrils and eyes are as ill-placed as our lips are ill-made - suddenly my eyes ceased to see, then my nose, crushed by the collision, no longer perceived any odor, and, without thereby gaining any clearer idea of the taste of the rose of my desire, I learned, from these obnoxious signs, that at least I was in the act of kissing Albertine's cheek. (Proust The Guermantes [1920/21] 1981, 379)

Marcel's sexual desire exists only insofar as he can perceive Albertine as a rose, which demarcates her sexual inversion and when he finally touches her, her seductiveness is destroyed. Bechdel also introduces proximity as destructive in relation to her own and her mother's relationship with Bruce. Further, she uses Proustian transubstantiation, that is, the conflation of human bodies with natural background to visually recreate Alison's inversion and introduce the father/daughter pair as semi-Oedipally united through her set of parallelisms with Remembrance.

Alison relates that Bruce first saw and fell in love with her mother during a college production of the Taming of the Shrew, when the former was playing one of the men and the latter had the leading role. Bruce is shown watching Helen from afar during her performance and Alison speculates "on what attracted [her] father more" between "the role, the actress [and Helen] herself" (Bechdel 2006, 69). Further, she explains that during her college years, her mother was living on Bleecker Street in Greenwich Village, and wonders "how much [... her] milieu factor[ed] into [Bruce's] attraction [to her]. Had he somehow conflated her with her address, like Proust's narrator had with Gilberte and the garden?" she wonders (105). Visually, Bruce is shown walking on the pavement on his way to Helen's place, exchanging gazes with a male passer-by. That Helen lived in an area distinguished by its thriving gay community seems, according to the narrator, as a factor 
that possibly attracted Bruce to her mother precisely because that space was marked by homosexual presence. While Alison speculates about the extent to which Helen's art and surrounding environment led to the escalation of Bruce's desire for her, proximity between the two, through marriage and family life, brought about collision, fighting, as well as mental and physical distance that harmed Alison's childhood.

When describing her OCD, and how she used to kiss her stuffed animals in order every night as a child, she notes that "though it verges on the bathetic, [...] no one had kissed me good night in years" (137). Earlier, she explains that "showing affection for [her father] was [a dicey] venture" (19). Once, she remembers, "I was unaccountably moved to kiss my father good night. Having little practice with the gesture, all I managed was to grab his hand and buss the knuckles lightly ... as if he were a bishop or an elegant lady, before rushing from the room in embarrassment" (19). Two panels visually recreate this awkward scene, illustrating Alison's inability to physically connect with and show emotions to her father. Proximity, therefore, leads to failure once again, and while Fun Home frequently illustrates this, Alison explains that she employs literary allusions to describe her parents because "they are most real to [her] in fictional terms. And perhaps," she proceeds, "my cool aesthetic distance itself does more to convey the arctic climate of our family than any particular literary comparison" (67). Bechdel's literary allusions and cool aesthetic distance do not merely mediate the cold climate in her family. They also, and most importantly, queer its structure. Hence, while Bruce's practices were perceived as injurious for her family relations by Alison as a child, they are reconfigured in Fun Home, to speak the unspeakable, to situate it within the family structure, and to thus present a queer version of it.

Bechdel's Proustian transubstantiation, the conflation of human bodies with natural background, visually recreates Alison's sexual inversion similarly to how it structures Bruce's on the chapter's title page. When she was ten years old, Alison went on a camping trip with her father, one of his male friends and her brothers. On their way to the mountains, she discovered a calendar 
with the picture of a nude female model in the car and remembers that she 'felt as if [she]' $d$ been stripped naked [...], inexplicably ashamed, like Adam and Eve" (Bechdel 112). The objectified female body caused feelings of shame and discomfort to Alison, whose clothed bodily stylization introduces a different gender representation than the one allowed by the nude spectacle. On the next page (fig.6), two panels demonstrate the contrast between the model and Alison's visual embodiment as a tomboy that is further underscored through Proustian transubstantiation. The first panel includes a close-up shot to the nude calendar model Alison is looking at. The angle of the panel also allows readers visual access to the autobiographical avatar, whose thought balloon mediates her surprise in what she faces.

The second panel shows her sat on a wooden pole that is balanced between the branches of two trees, looking at her brothers from afar, as they explore the calendar in excitement. Because of readers' distance from Alison and her brothers, it becomes possible to perceive her bodily stylization as very similar to theirs. In fact, like them, she wears shorts and a T-shirt ambivalently mirroring their looks. Further, she is situated in the forest like Gilberte, and she is sat on a wooden pole, which can be interpreted as a phallic symbol. Alison's conflation with the surrounding environment, a transubstantiation of sorts, underscores her representation as a tomboy and her identification with her father's ideal objects of desire. Bechdel's manipulation of the visual register of comics demonstrates the potential of the form to express unspeakable meanings and to parodically repair Alison's Freudian wound of femininity, at the same time as undermining biological sex and gender cohesion. Proustian transubstantiation is therefore described by the narrator and then translated into the visual register to release Alison from the restrictions of a heteronormatively sexed and gendered body. 

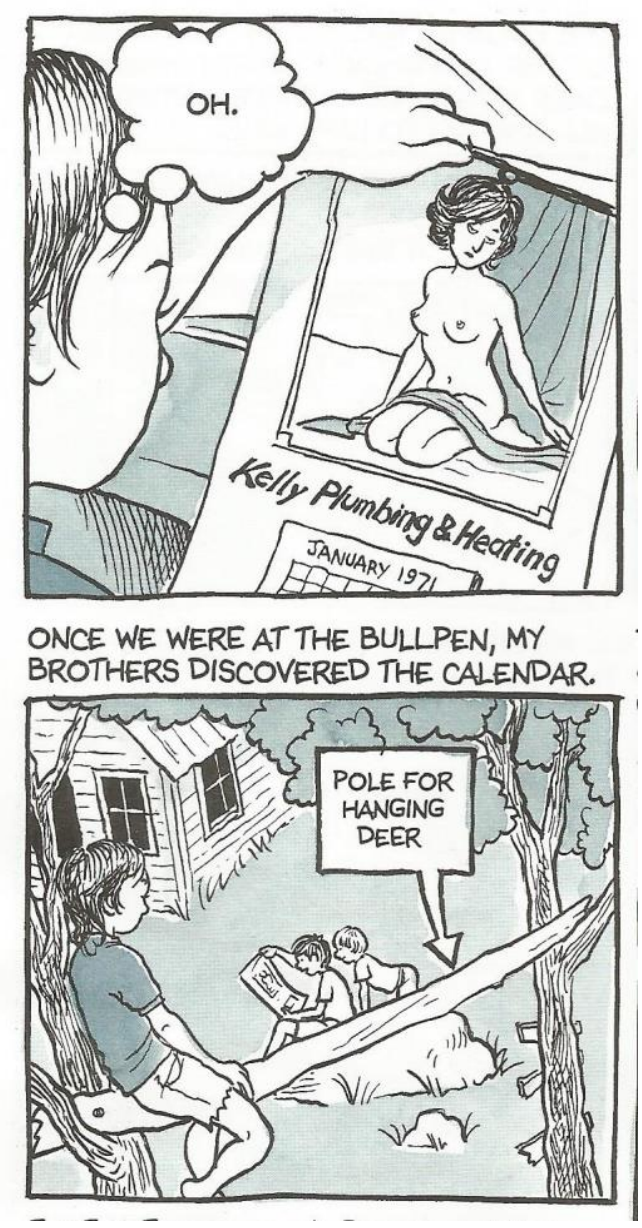

Figure 6: Panels 1 and 3, page 94 from: FUN HOME: A Family Tragicomic by Alison Bechdel. Copyright @ 2006 by Alison Bechdel. Reprinted by permission of Houghton Mifflin Company. All rights reserved.

The visuality of comics invests the autobiographical body with a plasticity that allows this release. Butler explains that "it is through the body that gender and sexuality become exposed to others, implicated in social processes, inscribed by cultural norms, and apprehended in their social meanings. In a sense, to be a body is to be given over to others even as a body is, emphatically, 'one's own'” $(2004,20)$. Bodies, according to Butler, are spectacles and sites of exposure that make us vulnerable to external gaze and violence. If language and our existence within a social context that fosters compulsory heterosexuality can become causes of violence and injury, Fun Home shows that comics can open up a space for the proliferation of visual embodiments that are no longer affected by these. Butler further suggests that, 
Always already a cultural sign, the body sets limits to the imaginary meanings that it occasions, but is never free of an imaginary construction. The fantasized body can never be understood in relation to another culturally instituted fantasy, one which claims the place of the "literal" and the "real." The limits of the "real" are produced within the naturalized heterosexualization of bodies in which physical facts serve as causes and desires reflect the inexorable effects of physicality. $(1999,96)$

Butler's description of the fantasised body that moves beyond the boundaries of heteronormativity applies to Bechdel's denaturalised bodily performances, which are conflated with the spatial background to allow the possibility of Alison's reclaiming of her father. Like Proust's Albertine, who is introduced as a hermaphroditic rose, Alison is conflated with the natural background for her “inversion" to be expressed.

In addition to Proust's flower/girl conflation, Alison mentions, as explained, that Proust transposed his beloved Alfred's gender into the fictional girl of Remembrance, Albertine. What she describes is introduced in Proustian criticism as the transposition theory. Justin O' Brien writes of Proust's affair with Agostinelli, a man who seemed "a real 'key' to the character of Albertine," associating the novelist's homosexuality to the creation of "the transposed [...] sex of Albertine" $(1949,935)$. O'Brien notes that to mask his homosexual desire for Agostinelli in his text, Proust had to create a form of a sexual inversion between the real Alfred and the fictional Albertine, to transpose his lover's male soul into a female body. Having provided readers with an introduction to transposition theory, Bechdel also uses it to construct the autobiographical avatar as Albertine, the masculine girl who is identified with Proust's beloved. To foreground this identification, the narrator relates an incident, which she remembers and reinterprets as an adult reader, aware of Proust's transposition model (see also Iuliano 2015). 
During their visit to the strip mine, Alison and her brothers were allowed entry by the operator of one of the cabs. After coming across another calendar with a nude female model, Alison explains that she felt "it seemed imperative that [the operator] not know [she] was a girl" (Bechdel 2006, 112). Having reached her decision, she asked her brother to "call [her] Albert instead of Alison," but he ignored her wish (112). "My brother ignored me," she notes, but "looking back, my stratagem strikes me as a precocious feat of Proustian transposition - not to mention a tidy melding of Proust's real Alfred and his fictional Albertine" (112). Thus, in Fun Home, Albertine transforms into a boy with Alison's attempt of passing and her wish to be called Albert. Identifying Bruce with Proust and Alison with Albertine, combined with Bechdel's reconfigured transubstantiation, allow a subtle construction of the father/daughter pair as a queer semi-Oedipal one. This structuring, however, is maintained only by preserving a distance between the two and conflating distinct diegetic realms in the space between the real life of Proust, the fictional world of Remembrance and the realm of the graphic memoir. Bechdel's childhood is thus remembered in ways that artificially reduce the physical distance between her autobiographical alter-ego and her father and the final panel of Fun Home (fig. 7) captures this remote reconnection between the two. Alison is depicted as a child, wearing a bathing suit, about to fall in her father's arms as he stands in a swimming pool. Situated above Bruce, she is about to physically touch him, but the panel freezes just before her fall, maintaining the distance between the two that preserves her desire and the potential of their reconnection.

\section{Towards a queer reunion}




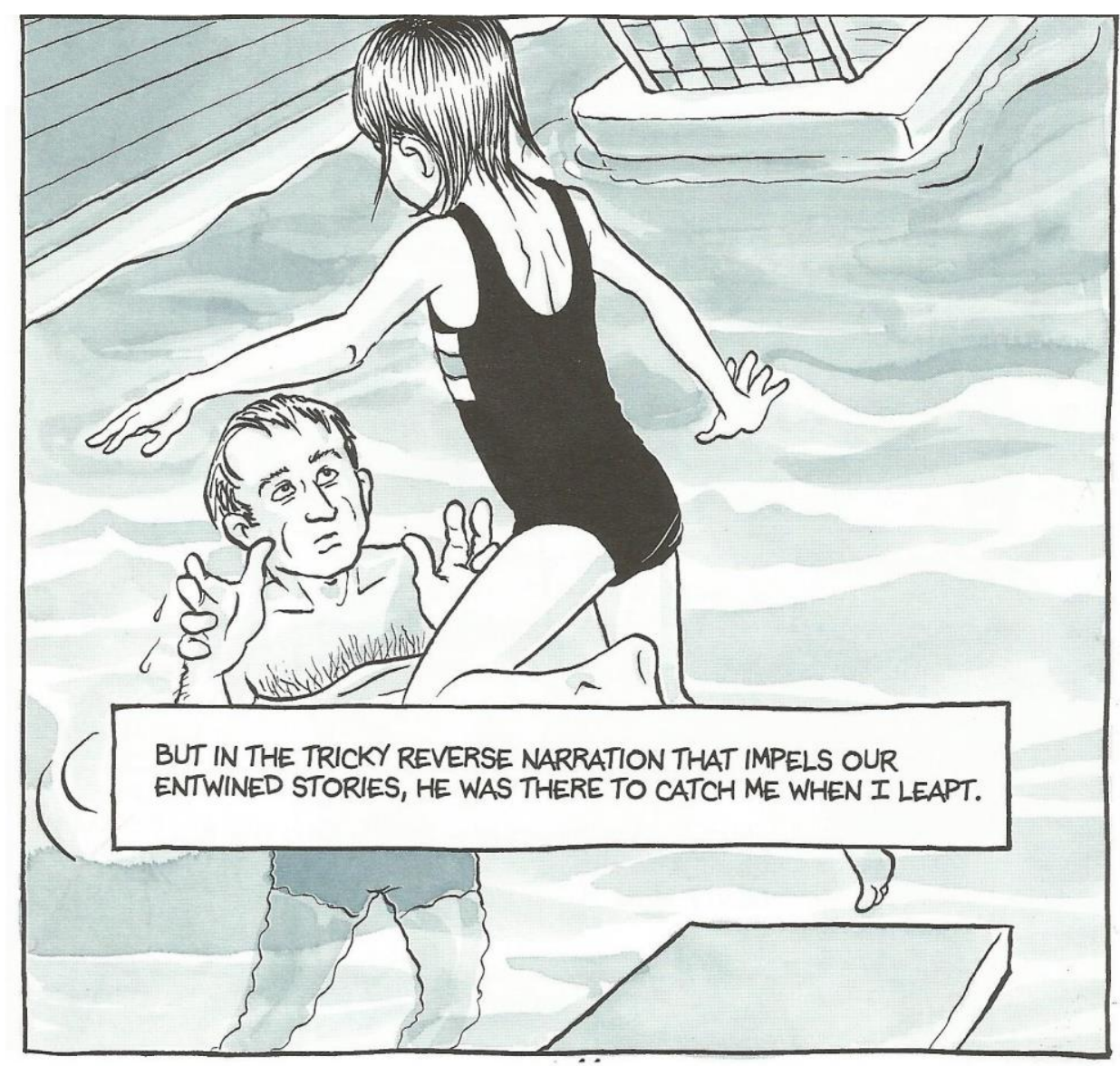

Figure 7: Panels 2, page 232 from: FUN HOME: A Family Tragicomic by Alison Bechdel. Copyright @ 2006 by Alison Bechdel. Reprinted by permission of Houghton Mifflin Company. All rights reserved.

Unlike her tomboy appearance throughout Fun Home, in this panel the protagonist's bathing suit brings her closer to a heteronormative feminine gender stylization. However, a different almost unnoticeable aspect of the panel signifies her identification with her father's object of desire and the representation of what I read as her semi-Oedipal reclaiming of Bruce. Looking at the panel carefully allows one to identify two dots at its bottom. The dots allude back to Bechdel's Proustian chapter, where the narrator explains how she felt when she discovered Roy's picture in a box of family photographs after her father's death. In the picture, which also functions as the book's centerfold, Roy lies on a bed in his underwear. When seeing it, Alison identifies, as she explains, with "her father's illicit awe" (Bechdel 2006, 100-101). The photograph functions as a trace that captures Bruce's homoerotic desire by visually embodying his lover and Alison's gaze implicates her in this desire. Being placed in the center of the book situates Roy in the center of this familial 
narrative and prevents the photograph from being interpreted in isolation and out of this context (see Scherr 2011). The narrator mentions that her father had "carefully blotted out" the year the picture was taken "and two small bullets on either side with a blue magic marker" (Bechdel 2006, 101). Nevertheless, she proceeds to explain that his "ineffectual attempt at censorship" leaves evidence about his homosexuality that is "simultaneously hidden and revealed," emblematic, really, of how he led his whole life (101). Alison fails to understand Bruce's reasoning behind the erasure of the two bullets, but Bechdel re-introduces them at the bottom of the book's final panel recreating and preserving a queer Oedipal connection between the father and the daughter through their insidious allusion to Roy's picture.

A few panels before the last one, Alison is drawn with the same bathing suit holding on to Bruce as both are swimming in the pool. Helen is drawn in the background once again, reading a newspaper. As Hillary Chute aptly suggests, in this scene "the father and daughter bodies are marked by their distinction from the normativity represented by the heterosexual mother they leave in their wake" $(2010,205)$. Bechdel's narrator explains that "perhaps [her] eagerness to claim [her father] as 'gay' in the way [she is] 'gay,' as opposed to bisexual or some other category, is just a way of keeping him to [her]self - a sort of inverted Oedipal complex" (2006, 230). In the visual register, the child autobiographical avatar is smiling as they are swimming, but by the end of the page she slips away from him and her look changes from indicating happiness to showing surprise and possibly fear as she is about to drift away from her father (see also Chute 2010). Alison's inverted Oedipal reclaiming of her father is preserved in the final panel of the narrative and underscored by the two dots precisely because the moment that is captured is the one just before touch, proximity and collision between the father/daughter pair.

This reclaiming complicates the narrative of Bruce's conflation of fiction, artifice and reality as a barrier for his relationship with Alison. In addition, it deconstructs the heterosexual binary divisions prescribed and reproduced in what Sigmund Freud describes as a child's "normal" 
Oedipal phase. According to Freud, in such a case a child identifies with, and becomes a rival to, the parent of the same sex, having as an object of desire the parent of the opposite sex, acquiring sex and gender cohesion and the same time as having his/her heterosexuality fixed (see [1922] 2001Beyond; Freud [1923] 2001 The Ego and the Id). In cases of inverted Oedipal complexes, the child identifies with, and becomes rival to, the parent of the opposite sex, having as an object of desire the parent of the same sex. Girls, for example, desire the mother, demonstrating masculine traits of behavior, becoming lesbians (see [1920] 2001 Beyond). In Fun Home, Alison identifies with Bruce in terms of their shared love for masculinity, but she does not refrain from Oedipally reclaiming him, despite how different their objects of desire are. The performance of her drive towards him undoes the view that identification presupposes the absence of desire, which is prescribed in the Freudian Oedipal complex (see also Pearl 2008). ${ }^{11}$

Julia Watson refers to a "sexual kinship" between Alison and Bruce and identifies Bechdel's refusal of "a coming out narrative of rebellion against paternal authority that opts for a pre-Oedipal fusing with the maternal" $(2008,42)$. She notes that instead, "Bechdel bonds with her [father] and revises her childhood yearning for erotic connection into a recognition of how she is like him" (42; see also Mitchell 2009). In agreement with Watson, I also argue that Alison bonds with her father in Fun Home, demonstrating, at the same time, that her identification with Bruce does not preclude the potential for the performance of an Oedipal drive towards him, causing in this way trouble to heteronormative family formations emerging from Freud's Oedipal model. Adrielle Mitchell also describes an Oedipal dynamic between Alison and her father, introducing Bruce's homosexuality as castration and feminisation, reading him as the "weak mother" whom Alison repudiates in favour of the father (2009, n.pag.). However, to reduce Bruce to a weak mother is to remain restricted within the binary restrictions of the Freudian Oedipal theory. It is by acknowledging the complexities and the potential of Fun Home's non-duality and of Alison and her father's ambiguous, denaturalized gender and sexuality performances, that readers can understand how the graphic memoir causes Butlerian trouble. 
Forgetting the heterosexual family as a source of origins is a method queer people should take up, according to Judith Halberstam, to deconstruct the power of heteronormative kinship bonds. Halberstam proposes that as queer people, we may have to "forget family in our theorizations of gender, sexuality, community, and politics and adopt forgetting as a strategy for the disruption of Oedipal transmission" $(2011,71)$. If forgetting the family can disrupt Oedipal dynamics and create a happy queer alternative, Fun Home shows that re-membering, repeating and reconfiguring it, through the comics form, by looking into what Ann Cvetkovich (2008) describes as "the queer archive" does so too. It demonstrates that remembering the family unit through the wiser adult artist's a posteriori knowledge of her father's homosexuality in relation to the autobiographical subject's "sexual inversion" can also queer the Oedipal complex. Thus, by recreating her familial past in this way, and through the performance Alison's Oedipal reclaiming for Bruce, Bechdel causes trouble. In her discussion on Butler's concept of "gender trouble" and specifically on the deconstruction of the division between identification and desire, Sara Ahmed points to the significance of queer trouble. She suggests that "we can think of trouble as an affective politics; acts of deviation mean getting in trouble but also troubling conventional ideas of what it means to have a good life that puts things into certain places. To cause trouble," she writes, "has effects" $(2010,117)$. The cultural significance of Fun Home lies precisely in that through its juxtapositions of text and image, and its intertextual references, it allows queer bodily performances that cause trouble by being distributed in ways that refuse to adhere to the heteronormative imperative.

\section{Coda}

Commenting upon Proust's Remembrance, Bechdel's narrator notes: “After dad died, an updated translation of Proust came out, Remembrance of Things Past was re-titled In Search of Lost Time. The new title is a more literal translation of $A$ la Recherche $d u$ Temps Perdu, but it still doesn't capture the full resonance of perdu. It means not just lost but ruined, undone, wasted, wrecked, and spoiled" (Bechdel 2006, 119). Fun Home recreates Alison's effort to make sense of her distant father, to 
reconcile with his death and recover from his loss. If we perceive her years in the family home as lost time, "wasted and ruined" because Bruce's closeted homosexuality drove him away from her, then by reinterpreting and recreating them through the comics medium, Bechdel creates a possibility both for the lost time and the lost father to be reclaimed. ${ }^{12}$ In addition, she foregrounds the potential of comics to complicate the reading process through her manipulation and reconfiguration of canonical literary influences and to trouble "our reliance on categories of high and low, included and excluded, straight and queer, textual and embodied" (Tolmie 2011, 79). As Ariella Freedman writes, Fun Home shows that "graphic narratives are the queer bastard child of high modernism" $(2009,138)$. As such, they are indeed promising for productive reconfigurations of elements from the modernist literary canon, for the performance of Butlerian gender trouble and of queer family structures (see also McCullough 2018). ${ }^{13}$ Thus, they can make significant contributions in "autographics" and queer life writing by offering spaces for positive, nuanced accounts of queer(-ed) lives and family relations.

\footnotetext{
${ }^{1}$ The French modernist author Marcel Proust is known primarily for his multi-volume novel $\grave{A} l a$ Recherche du Temps Perdu (1913-1927), translated in Scott C. K. Moncrieff and Terence Kilmartin's English edition as Remembrance of Things Past. Via figurative uses of language, the novel negotiates, inter alia, male homosexuality, defined as sexual inversion during the turn of the previous century (see Ellis 1933). Proust's use of metaphor for the articulation of sexual inversion is one of the most emblematic in the gay literary canon (see Bal 1999; Ladenson 1999; Lamos 2004; Ladenson 2016). In this essay, I propose that the medium of comics complicates and enriches Proust's figurative uses of language for the expression of Alison and Bruce's queer subjectivities. ${ }^{2}$ Critics have discussed Bechdel's intertextual references to other authors like Colette, Albert Camus, Scott Fitzgerald and William Faulkner among others (see Watson 2008; Freedman 2009; Chute 2010; Tolmie 20011; el Refaie 2012; Watson 2012). In this essay, I focus on Bechdel's references to Remembrance.
} 
${ }^{3}$ I refer to Judith Butler's "gender trouble" as a subversive reiteration of gender and sexuality norms that foregrounds the status of gender, sex and heterosexuality cohesion as a myth, by showing that sexuality and gender can exist beyond normalised binary masculine/feminine divisions (see Butler 1999).

${ }^{4}$ I refer to "failure" as a queer act that allows individuals to "escape punishing norms that discipline behaviour and manage human development with the goal of delivering us from unruly childhoods to orderly and predictable adulthoods," creating in this way alternative rewards for queer failing subjects (Halberstam 2011, 3).

${ }^{5}$ Butler explains that humans are "linguistic beings" invested with "linguistic vulnerability" because we are created via language, which can wound us by joining sex and gender divisions through, for example the use of the "he/she" pronouns, preventing the discursive articulations of troubling, non-binary gender identities $(1997,1 ; 1993,5)$.

${ }^{6}$ I use the term "autobiographical avatar" as introduced by Sidonie Smith and Julia Watson to refer to the drawn depictions of the narrated "I" in graphic narratives $(2010,169)$. I use "Bechdel" to refer to the author, "Alison" and "the narrator" interchangeably to refer to the narrator, "Alison" and "autobiographical avatar" to refer to her drawn depiction and "autobiographical subject" to refer to the narrated/drawn and narrating "I."

${ }^{7}$ The theory of sexual inversion was one of the first attempts to describe homosexuality during the turn of the previous century and it introduces inverts as people whose biological sex is the opposite of their gender (see Ellis 1933; Chauncey 1983). In her book, Female Masculinity, Judith Halberstam writes that "inversion both produced and described a category of biological women who felt at odds with their anatomy," and that "female masculinity" can be a basis through which to "explore a queer subject position that can successfully challenge hegemonic models of gender conformity" (1998, 82, 9; see also Ellis 1933). The term "invert" is also used by Alison to describe herself. 
${ }^{8}$ Elsewhere, I have also written about the central role of the reader in terms of identifying and interpreting intertextual references in Lynda Barry and Phoebe Gloeckner's graphic memoirs in ways that enrich and complicate their mise-en-scène narratives of childhood abuse and trauma (see Michael 2017; Michael 2018).

${ }^{9}$ Butler (2007) also refers to the potential of the visual arts for the construction of subversive gender and sexuality performances.

${ }^{10}$ Michael Lucey (2001) refers to Proust's “queer metalepses" and the appearance of Oscar Wilde, Balzac and the latter's fictional character, Lucien de Rubempré for the structuring of homoerotic desire in Remembrance (see also Lucey 2006).

${ }^{11}$ While the narrator describes what she identifies as Bruce's effeminacy, which is associated to gender representations rather than sexuality, apart from his depiction on the cover page of "In the Shadow," the rest of his visual representations in Fun Home do not demonstrate unconventional masculine bodily stylizations on behalf of Bruce. I read the narrator's comment as fusing homosexuality with effeminacy, similarly to how the term "invert" conflates the two by presenting the homosexual as a person whose gender is the opposite of their biological sex.

${ }^{12}$ Elsewhere, I explain that Fun Home performs what I describe as Bechdel's work of graphic healing through its intertextual references to Oscar Wilde and by presenting Bruce as a Wildean aesthete. This, I argue, indicates how Bechdel moves from being possessed by the past as a child unable to understand her father to possessing it and paying homage to him by giving him, in the realm of the graphic memoir, the life of the artist he had declined in favour of having a family (see Michael, 2020).

${ }^{13}$ Comics scholars have discussed the potential of Fun Home and other queer graphic life narratives as a means that can be used in educational contexts to unsettle the myth of cohesion between sex, gender and heterosexuality (see Scherr 2013, Morris 2015; Kedley and Spiering 2017). 
References:

Ahmed, S. 2010. The Promise of Happiness. Durham N.C.: Duke UP.

Bal, M. 1997. The Mottled Screen: Reading Proust Visually. Translated by A. L. Milne. Stanford, CA: Stanford UP.

Ball, M. D. 2013. “Allusive Confessions: The Literary Lives of Alison Bechdel's Fun Home.” In Drawing from Life: Memory and Subjectivity in Comic Art. Edited by J. Tolmie, 3-26. Jackson: Mississippi UP.

Bechdel, A. 2006. Fun Home: A Family Tragicomic. London: Jonathan Cape.

Butler, J. 1993. Bodies that Matter: On the Discursive Limits of "Sex.” New York: Routledge.

Butler, J. 1997. Excitable Speech: A Politics of the Performative. London: Routledge.

Butler, J. 2004. Undoing Gender. New York: Routledge.

Butler, J. 2007. Gender Trouble: Feminism and the Subversion of Identity. New York: Routledge.

Chauncey, G.Jr.1983. “From Sexual Inversion to Homosexuality.” Samlagundi 58/59: 114-46. http://www.jstor.org/stable/40547567.

Chute, L. H. 2010. Graphic Women: Life Narrative and Contemporary Comics. New York: Columbia UP.

Chute, L. H. 2016. Disaster Drawn: Visual Witness, Comics, and Documentary Form. Cambridge: Harvard UP.

Culler, J. 1976. "Presupposition and Intertextuality." Comparative Literature 91, 6: 1380-96. doi:10.2307/2907142.

Cvetkovich, A. 2008. "Drawing the Archive in Alison Bechdel's Fun Home." Women's Studies Quarterly 36, 1\&2: 111-28. doi:10.1353/wsq.0.0037.

Ellis, H. 1933. Studies in the Psychology of Sex. Vol. 2. Philadelphia: F.A. Davis Company.

Foley, K. S. 2004. Women in France since 1789: The Meanings of Difference. Basingstoke: Palgrave Macmillan. 
Fowlie, W. 1975. A Reading of Proust. London: Chicago UP.

Foucault, M.1998. The Will to Knowledge. Vol. 1 of The History of Sexuality. Translated by R. Hurley. London: Penguin.

Freedman, A. 2009. "Drawing on Modernism in Alison Bechdel's Fun Home." Journal of Modern Literature 32, 4: 125-40. https://muse.jhu.edu/article/315783.

Freud, S. 2001. Beyond the Pleasure Principle, Group Psychology and Other Works. Vol. 18 of The Standard Edition of the Complete Psychological Works of Sigmund Freud. Translated by J. Strachey, edited by J. Strachey and A. Freud. London: Vintage.

Freud, S. 2001. The Ego and the Id and Other Works. Vol 19 of The Standard Edition of the Complete Psychological Works of Sigmund Freud. Translated by J. Strachey, edited by J. Strachey and A .Freud. London: Vintage.

Genette, G. 1980. Narrative Discourse: An Essay in Method. Translated and edited by J. Culler. Ithaca, NY: Cornell UP.

Guenther, L. 2010. “Other Fecundities: Proust and Irigaray on Sexual Difference.” A Journal of Feminist Studies 21,2: 24-45. https://doi.org/10.1215/10407391-2010-002.

Halberstam, J. 1998. Female Masculinity. London: Duke UP.

Halberstam, J. 2011. The Queer Art of Failure. Durham, NC: Duke UP.

Iuliano, F. 2015. “Du Côté de Fun Home: Alison Bechdel Rewrites Marcel Proust.” Partial Answers: Journal of Literature and the History of Ideas 13,2: 287-309. doi:10.1353/pan.2015.0016.

Kedley, E. K. and J.Spiering. 2017. "Using LGBTQ Graphic Novels to Dispel Myths about Gender and Sexuality in ELA Classrooms." English Journal 107,1:54-60. http://www.ncte.org/library/NCTEFiles/Resources/Journals/EJ/1071sep2017/EJ1071LGBTQ.pdf.

Kristeva, J. 1993. Proust and the Sense of Time. Translated by S. Bann. London: Faber and Faber. 
Ladenson, E. 1999. Proust's Lesbianism. London: Cornell UP.

Ladenson, E. 2016. “Literature and Sex.” In The Cambridge Companion to French Literature.

Edited by J. D. Lyons, 222-41. Cambridge: Cambridge UP.

Lamos, C. 2004. Deviant Modernism: Sexual and Textual Errancy in T.S. Eliot, James Joyce, and Marcel Proust. Cambridge: Cambridge UP.

Larson, J, F. Saggini and A. Soccio Larson. 2012. "Housing Fictions in Time: An Introduction." European Journal of English Studies 16,1: 1-8. https://doi.org/10.1080/13825577.2012.655160.

Lemberg, J. 2008. “Closing the Gap in Alison Bechdel's Fun Home.” Women's Studies Quarterly 36, 1\&2: 129-40. doi:10.1353/wsq.0.0051.

Lucey, M. 2001. “Proust's Queer Metalepses.” MLN 116,4: 795-815. doi:10.1353/mln.2001.0058.

Lucey, M. 2006. Never Say I: Sexuality and the First Person in Colette, Gide and Proust. London: Duke UP.

Lydenberg, R. 2012. "Under Construction Alison Bechdel's Fun Home: A Family Tragicomic." European Journal of English Studies 16,1: 57-68. https://doi.org/10.1080/13825577.2012.655158.

Lydenberg, R. 2017. "Reading Lessons in Alison Bechdel's Fun Home: A Family Tragicomic." College Literature 44,2: 133-65. https://muse.jhu.edu/article/656972.

McCloud, S. 1994. Understanding Comics. New York: HarperCollins.

McCullough, K. 2018. “"The Complexity of Loss Itself”: The Comics Form and Fun Home's Queer Reparative Temporality.” American Literature 90,2: 377-405. https://doi.org/10.1215/00029831-4564346.

Meyer, R. 2002. Outlaw Representation: Censorship and Homosexuality in Twentieth-Century Art. Oxford: Oxford UP. 
Michael, O. 2017. "Excavating Childhood: Fairy Tales, Monsters and Abuse Survival in Lynda Barry' What It Is.” a/b: Auto/biography Studies 32, 3:541-66. doi.org/10.1080/08989575.2017.1338002.

Michael, O. 2018. “The Other Narratives of Sexual Abuse in Phoebe Gloeckner's A Child's Life and Other Stories." Journal of Graphic Novels and Comics 9,2: n.pag. doi.org/10.1080/21504857.2018.1462223.

Michael, O. 2020. “Queer Trauma, Paternal Loss and Graphic Healing in Alison Bechdel's Fun Home: A Family Tragicomic. In Arts of Healing: Cultural Narratives of Trauma. Edited by Arleen Ionescu and Maria Margaroni, n.pag. London: Rowman \& Littlefield.

Mitchell, A. 2009. "Spectral Memory, Sexuality and Inversion: An Arthrological Study of Alison Bechdel's Fun Home: A Family Tragicomic." ImageText: Interdisciplinary Comics Studies 4,3: n.pag. http://www.english.ufl.edu/imagetext/archives/v4_3/mitchell/.

Moffat, W. 2015. “The Narrative Case for Queer Biography.” In Narrative Theory Unbound: Queer and Feminist Interventions. Edited by R. Warhol and S. Lanser, 175- 87. Columbus: Ohio State UP.

Morris, J. 2015. "Multimodal Literacies and Graphic Memoir: Using Alison Bechdel in the Classroom," Composition Studies 43,1: 193-214. https://search.proquest.com/docview/1753217330?accountid=17233.

Moyise, S. 2002. "Intertextuality and Biblical Studies: A Review.” Verbum et Ecclesia 23, 2: 41831. http://hdl.handle.net/2263/10735.

O’ Brien, J. 1949. “Albertine the Ambiguous: Notes on Proust's Transposition of Sexes.” Modern Language Association, 64,5: 933-52. DOI:10.2307/459544.

Pearl, B. M. 2008. “Graphic Language: Redrawing the Family (Romance) in Alison Bechdel's Fun Home." Prose Studies 30,3: 286-304. https://doi.org/10.1080/01440350802704853. 
Proust, M. 1981. Remembrance of Things Past. Vols.1-2. Translated and edited by C. K. S. Moncrieff and T. Kilmartin. London: Chatto \& Widnus.

Refaie, el, E. 2012. Autobiographical Comics: Life Writing in Pictures. Jackson: Mississippi UP. Rohy, V. 2010. "In the Queer Archive: Fun Home." Journal of Gay and Lesbian Studies 16,3: 340-61. muse.jhu.edu/article/382220.

Scherr, R. 2011. "Queering the Family Album: The Re-orientation of Things in Alison Bechdel's Fun Home." Forum for World Literature Studies 3,1: 40-51.

Scherr, R. 2013. “'Teaching the 'Auto-Graphic Novel:' Autobiographical Novels and the Ethics of Readership.” In Graphic Novels and Comics in the Classroom: Essays on the Educational Power of Sequential Art. Edited by C. K. Syma and R. G. Winer, 134-44. Jefferson: McFarland \& Company.

Schlick, Y. 2013. "What is an Experience? Selves and Texts in the Comic Autobiographies of Alison Bechdel and Lynda Barry." In Drawing from Life: Memory and Subjectivity in Comic Art. Edited by J. Tolmie, 26-44. Jackson: Mississippi UP.

Sedgwick Kosofsky E. 1991. Epistemology of the Closet. London: Harvester Wheatsheaf.

Smith, S. and J. Watson. 2010. Reading Autobiography: A Guide for Interpreting Life Narratives. Minneapolis: U of Minnesota P.

Splitter, R. 1978. "Proust, Joyce and the Theory of Metaphor." http://authors.library.caltech.edu/13687/1/HumsWP-0003.pdf.

Strange, S.L. 2002. “The Bicycle, Women's Rights, and Elisabeth Cady Stanton,” Women's Studies: An Interdisciplinary Journal 31,5: 609-26. https://doi.org/10.1080/00497870214048.

Syme, A. 2010. A Touch of Blossom: John Sargent and the Queen Flora of Fin-de-Siècle Art. University Park: Pennsylvania State UP. 
Tison, H. 2015. “Loss, Revision, Translation: Re-Membering the Father's Fragmented Self in Alison Bechdel's Graphic Memoir Fun Home." Studies in the Novel 47,3: 346-64. doi:10.1353/sdn.2015.0043.

Tolmie, J. 2011. "Modernism, Memory and Desire: Queer Cultural Production in Alison Bechdel's Fun Home." Topia 22: 77-95. DOI: 10.3138/topia.22.77.

Watson, J. 2008. “Autographic Disclosures and Genealogies of Desire in Alison Bechdel's Fun Home.” Biography 31,1: 27-58. doi:10.1353/bio.0.0006.

Watson, J. 2012. “The Pleasures of Reading in Alison Bechdel's Fun Home.” Life Writing 9,3: 303-14. https://doi.org/10.1080/14484528.2012.692652.

Whitlock, G. 2006. “Autographics: The seeing 'I' of Comics.” MFS: Modern Fiction Studies 52,4: 965-79. doi:10.1353/mfs.2007.0013.

Whitlock, G. and A. Poletti. 2008. "Self-Regarding Art.” Biography: An Interdisciplinary Quarterly 31, 1: v- xxiii. https://doi.org/10.1353/bio.0.0004. 